Logos Universality Mentality Education Novelty, Section:

Economical and Administrative Sciences

ISSN: 2284-5984 (print), ISSN: 2284 - 5984 (electronic)

Covered in: CEEOL, Index Copernicus, Ideas RePeC, EconPapers, Socionet

\title{
CONTEMPORARY CHALLENGES FACING LOCAL GOVERNMENT
}

\section{Gabriela NEMTTOI}

Doi: http://dx.doi.org/10.18662/lumeneas.2015.0201.01

Logos Universality Mentality Education Novelty, Section: Economical and Administrative Sciences, 2015, Volume II, Issue 1, pp: $7-10$

Published by:

Lumen Publishing House

On behalf of:

Lumen Research Center in Social and Humanistic Sciences 


\title{
Contemporary Challenges Facing Local Government
}

\author{
Gabriela NEMT,TOI ${ }^{1}$
}

\begin{abstract}
The theme of this paper deals with the idea of leadership implementation in the public service as a challenge for the public administration system. Leadership plays an important role in the system of government because it involves two aspects of the required administrative reform, namely: change and people. Changing public institutions represents changing the mentalities and the behaviour of employees, which means that institutions passing through reform need leadership. The leaders of public institutions can help promote and maintain new values that are necessary for a successful public sector reform.

To streamline the administrative reform, public leadership clearly includes the heads of central public administration and political leaders. In this regard, depending on the implemented programs, we can discuss about a successful reform in public administration or an organizational standstill.

As a conclusion, this article will focus on several issues related to the implementation of leadership in the public service as a challenge for public institutions.
\end{abstract}

Keywords: leadership, public administration, public institutions, public organizations, leader.

${ }^{1}$ Stefan cel Mare University, Suceava, Romania, gabrielan@seap.usv.ro.

Nemtoi, G. (2015). Contemporary Challenges Facing Local Government. Logos Universality Mentality Education Novelty, Section: Economical and Administrative Sciences, II (1), 7-10. Doi: http://dx.doi.org/10.18662/lumeneas.2015.0201.01 


\section{Introduction}

Leadership is considered an important element contributing to the success or failure of an institution development and hence the performance of the service the institution is rendering, in the public space. It is known that many of the public institutions or organizations, operating in the public domain, refer to creating some programs or achieving some objectives. These strategic activities are the responsibility of management of the institution, which motivates leadership development (Starling, 2010, p. 14).

Leadership is very important when it comes to relations between members of the organization and motivation of the staff of public institutions.

Knowing that employees (civil servants) of an organization / public institutions, generally, are poorly encouraged materially; managers (formal leaders) must compensate this lack and find appropriate ways to stimulate employees to achieve organizational objectives.

The study of managerial behaviour (or the study of leadership styles), exhibit importance to the public sector for the following reasons (Zlate, 2009):

- Practicing a certain managerial bebaviour - style of coordination used by management influences the employee's activity, with effects on the psychological, socio-affective, relational climate of public institutions and on labour productivity,

- Style of leadership - influences how subordinates perceive the leader.

As we stated earlier, the success or failure of a public institution is related to the leadership practiced.

\section{Identifying the Leadership formula in public institutions as central element in the administrative system}

Overall, the economic, political or administrative disaster concerns the lack of leadership, and for a politician or a civil servant, the ultimate insult can be the finding of shortcomings in this area.

Regarding the status of leaders within public organizations, we have to do with a consistent set of myths like: the decision making is rational, leaders control all aspects of organizational life, develop coherent strategies, deal with the problems occurred, benefit from complex and efficient computerized information systems and competent advisers etc., phenomena

Nemtoi, G. (2015). Contemporary Challenges Facing Local Government. Logos Universality Mentality Education Novelty, Section: Economical and Administrative Sciences, II (1), 7-10. Doi: http://dx.doi.org/10.18662/lumeneas.2015.0201.01 
that are not quite real. Consequently, the leadership technic stores the explanation to these situations.

In reality, the problem of public organizations management lies not in this ordered and predictable context; characteristics of leadership in public administration are more prosaic: decisions are often reactive, based on intuition and experience, loads of detail crowd to the brim the agenda and a secondary strategic decisions and the manager work tends to be much less related to elements of rationality, predictability and control.

Thus, one of the important factors that must be considered when we study leadership and its implications in the local or central government, refers to public sector specific. Specifically, the characteristics of this sector, which differentiates it from the private sector or the non-governmental.

Next, we analyse the specific characteristics of the public sector that influence leadership. Most often, when we talk about the public sector we consider the structure of the public administration as a whole, be it central Government or local authorities. Even if public organizations currently have an extremely complex structure and varies substantially from state to state, there are a number of features that are found in every administrative system and which differentiates them from private organizations.

From a general perspective, the leader holds a unique position within the group (public institutions) and we talk about leadership, other members of the group (subordinates) must accept this position. Derogate to practice, a Government's activity will be assessed by the activity of the prime minister and the activity of a mayor will be assessed based on the services that provides the institution he leads through its employees.

Such public institutions according to Philip Selznick (1983, p. 68), the leader is identified by four functions:

- Defining the role and mission of the organization (institution),

- Representing institutional goals,

- Safeguarding the integrity of the institution (organization),

- Control of internal conflicts.

Organizational performances depend on how each leader sees to submit to subordinates to achieve the goal of the organisation and to involve them in decision-making.

Activities such as: setting development directions, forming and maintaining a team spirit, promoting results-oriented, defending the integrity of the institution; were activities considered specific only to leadership, not to management. According to recent opinion, that we rally, this 
differentiation does not have to be so rigid, but more flexible (Jreisat, 2012, p. 164).

\section{Conclusions}

In conclusion we can say that serving public institutions from public administration, can be assessed also in the context in which the relationship between departments is implemented the phenomenon of leadership, on the one side, and on the other side, the objectives are meet only if the main officer is able to correctly and consistently apply a policy to optimize human resources services, to find the effect in the primary source i.e. the public official. In this regard, we identify possible areas of leadership exploitation through studies carried out in public institutions.

\section{Reference}

Jreisat, J. E. (2012). Globalism and Comparative Public Administration. New York: CRC Press. p.164

Selznick, P. (1983). Leadership in Administration. Engelska: Ed POCKET.

Starling, G. (2010). Managing the Public Sector, Ninth Edition. UK: Wadsworth Publishing.

Zlate, M. (2009). Fundamentele Psihologiei. Romania: Ed. Polirom.

\section{Biodata}

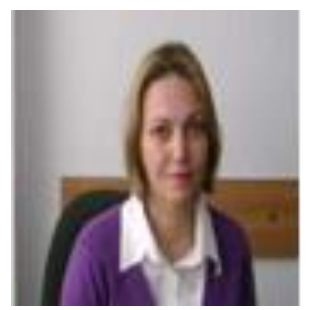

\section{Lecturer PhD Gabriela NEMT,OI}

Lecturer Ph.D. Stefan cel Mare University Suceava, Department of Public Administration and Law, Specialty author of four books of Constitutional Law, participating in national and international conferences, author of over 50 papers published in Thomson ISI database, director of international projects in the field of civil law. Currently it operates research and teaching in the field of constitutional, law civil.

Nemtoi, G. (2015). Contemporary Challenges Facing Local Government. Logos Universality Mentality Education Novelty, Section: Economical and Administrative Sciences, II (1), 7-10. Doi: http://dx.doi.org/10.18662/lumeneas.2015.0201.01 